\title{
Science and innovation in malaria diagnostics
}

\author{
Sanjeev Krishna*, NanoMal \\ From Challanges in malaria research: Core science and innovation \\ Oxford, UK. 22-24 September 2014
}

Five species of Plasmodium naturally infect humans. Some species cause non-specific symptoms that can sometimes progress rapidly to severe and fatal outcomes. Early diagdoi:10.1186/1475-2875-13-S1-019

Cite this article as: Krishna and : Science and innovation in malaria nosis and appropriate treatment interrupts progression and cures disease. Confirmation of diagnosis of malaria currently relies on microscopy, or on application of rapid diagnostic tests (RDTs) that are becoming increasingly widely available and are recommended to confirm infection before treating it. The diagnosis of malaria by itself is not sufficient to optimise individual therapies because there is a growing problem of multidrug resistance in parasites (particularly Plasmodium falciparum). This limits the use of some drugs or combinations by severely compromising their efficacy.

Diagnostic strategies for management of malaria can therefore be improved in several ways. First by an increase in sensitivity of detection of parasites that should improve of the thresholds for detection by the current generation of RDTs because they cannot identify low parasitaemias. Second, a diagnostic that can differentiate all the naturally infecting species of parasite needs to be developed. Finally, rapid (point-of-care) assessment of the drug resistance status of parasites will add greatly to the treatment strategies available to manage individual patients. Technological platforms that can deliver information that is currently missing for the personalised management of malaria infections are being developed and these advances will be presented and discussed in the context of the global burden of disease caused by malaria.

Acknowledgements

Funded by a grant from the EU under the FP7 innovations programme.

Published: 22 September 2014

St. George's, University of London, UK

diagnostics. Malaria Journal 2014 13(Suppl 1):O19.

Submit your next manuscript to BioMed Central and take full advantage of:

- Convenient online submission

- Thorough peer review

- No space constraints or color figure charges

- Immediate publication on acceptance

- Inclusion in PubMed, CAS, Scopus and Google Scholar

- Research which is freely available for redistribution

Submit your manuscript at www.biomedcentral.com/submit
() Biomed Central

\section{() Biomed Central}

